\title{
SEMANTIK PROTOTIPE KORUPSI: KAJIAN LINGUISTIK KOGNITIF
}

\author{
Millatuz Zakiyah, Noveria Anggraeni Fiaji, Prima Zulvarina \\ Pusat Mata Kuliah Pengembangan Kepribadian (PMPK), Universitas Brawijay a \\ Jalan Veteran, Lowokwaru, Malang, Jawa Timur \\ Surel: novafiaji@ub.ac.id
}

Informasi Artikel:

Dikirim: 4Februari 2018; Direvisi: 20 April 2018; Diterima:30 Juli 2018

DOI: 10.26858/retorika.v11i2.5137

RETORIKA: Jurnal Bahasa, Sastra dan Pengajarannya berada di bawah lisensi

Creative Commons Attribution-NonCommercial 4.0 International License.

ISSN: 2614-2716 (cetak), ISSN: 2301-4768 (daring)

http://ojs.unm.ac.id/retorika

\begin{abstract}
Semantics Corruption Prototype: Cognitive Linguistic Study. Semantic Prototype Corruption: Cognitive Linguistics Review. This study aims to define corruption through prototype theory in cognitive linguistics. The research is designed through a qualitative-quantitative approach with Tomaszczyk (2007) prototype theory. The results of the study indicate that the most corrupt variables affecting the degree of corruption are (1) 'unlawful rewards' and (2) 'abuse of authority', while (3) 'knowing that it is corruption' and (4) 'corrupt intent' no effect. This finding confirms that in the prototype study there are two aspects that affect the degree of prototype of a category, namely the member variables and the background of the respondent.
\end{abstract}

Abstrak: Semantik Prototipe Korupsi: Kajian Linguistik Kognitif. Penelitian ini bertujuan mendefinisikan korupsi melalui teori prototipe dalam linguistik kognitif. Penelitian didesain melalui pendekatan kualitatif-kuantitatif dengan ancangan teori prototipe Tomaszczyk (2007). Hasil penelitian menunjukkan bahwa variabel korupsi yang paling memengaruhi derajat korupsi adalah (1) 'terdapat imbalan yang tidak sah' dan (2) 'terdapat penyalahgunaan kewenangan', sedangkan (3) 'tahu bahwa itu korupsi'dan (4) 'niat korupsi' tidak berpengaruh. Temuan ini menegaskan bahwa dalam kajian prototipe terdapat dua aspek yang memengaruhi derajat prototipe suatu kategori, yaitu variabel anggota kategori dan latar belakang responden.

Kata kunci: korupsi, linguistik kognitif, semantik prototipe 
Pada tahun 2017, Indonesia Corruption Wacth (ICW) melaporkan bahwa korupsi yang terjadi sebanyak 576 kasus, jumlah tersangka 1.298 orang, dan kerugian negara sebesar 6,5 triliun. Hal ini menjadi indikasi bahwa kasus korupsi di Indonesia masih sangat tinggi dan belum memberikan efek jera bagi para pelakunya. Azra (2002) menyatakan bahwa korupsi merupakan masalah terbesar yang dihadapi Indonesia yang bahkan telah menjadi budaya yang berurat akar. Oleh sebab itu, sebaiknya pemerintah tidak tebang pilih dalam memberikan efek jera pada para terpidana kasus korupsi.

Tanzi (1998) mendefinisikan korupsi sebagai penyalagunaan kekuasaan untuk kepentingan pribadi. Dalam Kamus Besar Bahasa Indonesia (2008), kata 'korupsi' didefinisikan sebagai penyelewengan atau penyalahgunaan uang negara (perusahaan dsb.) untuk keuntungan pribadi atau orang lain. Definisi lain korupsi dapat ditemukan melalui Undang-undang Nomor berdasarkan Peraturan $\mathrm{Pe}$ merintah Pengganti Undang-Undang Nomor $24 \mathrm{Ta}$ hun 1960 tentang Pengusutan, Penuntutan, dan Pemeriksaan Tindak Pidana Korupsi mengatakan bahwa,

tindakan seseorang yang dengan atau karena melakukan suatu kejahatan atau pelanggaran memperkaya diri sendiri atas orang lain atau suatu badan yang secara langsung atau tidak langsung merugikan perekonomian negara atau daerah atau badan hukum lain yang mempergunakan modal dan kelonggaran-kelonggaran dari negara atau masyarakat.

Definisi-definisi tersebut memandang korupsi melalui komponen-komponen tertentu yang membangunnya, seperti tindakan yang merugikan negara, menguntungkan diri sendiri, dan penyalahgunaan kewenangan. Pendefinisian yang diperoleh dari kata korupsi tidak dapat secara serta merta diartikan sebagai arti kata karena definisi memiliki karakteristik tertentu. Teknik dalam menyusun sebuah definisi bisa dikualifikasi berdasarkan dua macam, yaitu arti intensional dan arti ekstensional. Dibutuhkan proses yang matang dalam menganalisis dan membangun definisi suatu kata. Salah satu komponen yang dapat digunakan untuk membangun suatu kata adalah analisis komponensial.
Pendefinisian suatu kata melalui teknik analisis komponensial memiliki keterbatasan mengingat kreativitas manusia yang tidak terbatas. Padahal, analisis komponensial hanya menganalisis makna kata berdasarkan unsur-unsur leksikal melalui komponen, fitur, penanda, dan pembeda dari kata yang dimaksud (Lyons, 1979:323). Sementara itu, kreativitas manusia dalam memandang sesuatu menjadikan batasan suatu kata menjadi kabur. Makna kata tidak lagi dapat ditentukan oleh ada tidaknya komponen semantis tertentu, tetapi bergantung pada jarak prototipe (Kushartanti, dkk., 2010: 121). Lebih dari itu, Geeraerts (2016) menyatakan bahwa terdapat fenomena penyembunyian makna kata jika hanya pendekatan struktural, dalam hal ini analisis komponensial, yang digunakan dalam pendefinisian makna kata. Sebagai contoh, istilah "seni" yang dapat dipahami berbeda oleh berbagai orang. Sebagian orang menganggap lukisan X sebagai seni, sedangkan yang lain melihatnya sebagai sesuatu yang tabu. Begitu juga kata "bebas" yang bagi sebagian orang berarti tanpa batas, tetapi bagi sebagian lain masih memiliki batas.

Perbedaan-perbedaan tersebut disebabkan berbagai faktor, seperti faktor pendidikan, gender, kelas sosial, dan sebagainya. Perbedaan ini tidak dapat dijelaskan dengan baik jika hanya melalui analisis komponensial. Oleh karena itu, muncul teori prototipe untuk menjawab celah analisis semantis yang tidak mampu menjelaskan leksem-leksem yang tidak mempunyai komponen makna yang jelas (Pasaribu, 2013:23). Prototipe adalah representasi atau perwakilan yang abstrak dari sebuah kategori atau bagian dari kategori yang digunakan sebagai acuan dalam menentukan keanggotaan sebuah kategori (Rosch \& Mervis dalam Lipka, 1986: 85)

Kajian korupsi dalam ranah linguistik belum banyak dilakukan. Selama ini, penelitian tentang korupsi lebih banyak dititikberatkan pada ranah hukum dan politik, seperti tulisan Azra (2002) tentang korupsi dalam perspektif good governance yang mengkaji korupsi dalam ranah politik dilihat dari definisi dan strategi penanganan korupsi. Definisi korupsi dalam tulisan ini diarahkan pada penelitian terdahulu yang dilakukan ahli lain dari luar Indonesia. Hal ini menunjukkan bahwa definisi yang ditawarkan masih berkerangka universal.

Penelitian selanjutnya dilakukan Sina (2008) 
yang mengkaji dampak dan upaya pemberantasan serta pengawasan korupsi di Indonesia. Penelitian itu memandang korupsi dalam kerangka hukum. Korupsi didefinisikan berdasarkan teori ahli, Undang-Undang Nomor 31 Tahun 1999 tentang Pemberantasan Tindak Pidana Korupsi, dan undang-undang tentang korupsi lainnya. Selain memaparkan tentang definisi, tulisan itu melihat pula dampak korupsi terhadap keuangan, perekonomian, dan pembangunan negara serta upaya pemberantasan korupsi di Indonesia.

Penelitian korupsi dalam kajian linguistik yang telah dilakukan adalah penelitian Ayatullah (2014). Penelitian ini menggunakan ancangan wacana kritis yang merupakan perpaduan kajian linguistik dan komunikasi. Melalui kajian itu ditemukan bahwa pada surat kabar Malang Post terdapat dua wacana yang merupakan representasi kasus Hambalang, yaitu wacana hukum dan korupsi (kasus Hambalang sebagai tindak pidana korupsi yang harus ditindaklanjuti) dan wacana politik dan kekuasaan (adanya konspirasi dan konflik kepentingan dari para elit politik dalam kasus tersebut). Penelitian Ayatullah (2014) berbeda dengan pendekatan dengan pendekatan penelitian ini.

Selanjutnya, Prayudha (2013) mengkaji kata 'penyuapan' dalam ranah linguistik antropologis. Akan tetapi, penelitian ini menggunakan ancangan teori prototipe yang notabene merupakan ranah lingusitik kognitif untuk mendekati korupsi dari sisi budaya. Simpulan penelitian tersebut dapat dianggap kurang tepat karena ketidaktepatan pemilihan pendekatan penelitian.

Sebagai bagian dari 'budaya', korupsi memiliki peluang untuk dibahas dari kajian bahasa. Penelitian ini membahas prototipe 'korupsi' dalam kognisi orang Indonesia. Selama ini, pendefinisian kata 'korupsi' dalam ranah bahasa masih sebatas analisis komponensial. Oleh karena itu, penelitian ini bertujuan untuk menjelaskan kata korupsi dalam kajian semantik kognitif yang diteliti melalui analisis prototipe.

Penelitian sebelumnya terkait prototipe dilakukan oleh Nurjannah (2013) yang melihat protipe leksem bule dalam kognisi orang Indonesia. Hal ini tentu berbeda dengan penelitian ini yang melihat prototipe leksem korupsi. Dengan demikian, penelitian ini dapat berkontribusi terhadap pengembangan teori semantik prototipe.

\section{METODE}

Penelitian ini merupakan jenis penelitian metode campuran atau mixed method. Creswell (2012:5) mengungkapkan bahwa penelitian campuran adalah pendekatan penelitian yang mengombinasikan atau mengasosiasikan bentuk kualitatif dan bentuk kuantitatif. Pendekatan ini lebih kompleks dari sekedar mengumpulkan dan menganalisis dua jenis data. Jenis penelitian ini juga melibatkan fungsi dari dua pendekatan penelitian secara kolektif sehingga kekuatan penelitian ini secara keseluruhan lebih besar daripada kualitatif dan kuantitatif.

Untuk menguji semantik kognitif, penelitian ini menggunakan langkah penelitian kualitatif dan kuantitatif. Penelitian semantik kognitif adalah penelitian bahasa sehingga secara khusus penentuan variabel dan sumber data menyesuaikan penelitian yang mengadatasi dari Coleman dan Kay (1981).

Sumber data pada penelitian ini adalah responden yang dapat memberikan jawaban melalui angket. Responden dikhususkan dari Universitas Brawijaya yang berasal dari kalangan dosen dan mahasiswa. Selain itu, responden dari kalangan dosen dan mahasiswa juga dibedakan dari latar belakang pendidikan hukum dan non-hukum. Hal tersebut bertujuan agar pemerolehan makna secara umum tentang "korupsi" dapat terlihat. Data penelitian berbentuk hasil angket dari responden. Jumlah responden ditentukan oleh kejenuhan data dengan memperhatikan keseimbangan responden pada klasifikasi masing-masing. Jika data telah jenuh, pengumpulan data dihentikan dan dilanjutkan pada klasifikasi dan analisis data.

Teknik pengumpulan data diadaptasi dari Coleman dan Kay (2014). Tahap pertama dilakukan dengan menentukan variabel kata 'korupsi'. Variabel tersebut adalah (1) penyalahgunaan kewenangan, (2) terdapat imbalan yang tidak sah, (3) tahu kalau itu korupsi, dan (4) ada niat untuk korupsi. Dalam penelitian ini, korupsi dibatasi pada korupsi yang berkaitan dengan negara. Penyalahgunaan kewenangan sekaligus menunjukkan bahwa korupsi berhubungan dengan pihak yang memiliki jabatan. Imbalan yang tidak sah berhubungan dengan pemberian janji atau sesuatu yang tidak sesuai dengan aturan yang berlaku. Sementara itu, va- 
riabel (4) bergantug pada variabel (3). Artinya, jika variabel (3) bernilai (-) secara otomatis variabel (4) pun (-). Hal ini didasari argumentasi bahwa tidak logis jika seorang berniat korupsi tanpa memahami bahwa itu korupsi.

Tahap kedua, menyusun kuisioner penelitian sebagai alat pengumpulan data. Kuisioner penelitian ini berupa 12 ilustrasi yang berisi variabel korupsi dengan susunan yang berbeda. Jenis angket yang digunakan dalam penelitian ini adalah angket terbuka, yaitu angket yang sudah disediakan jawabannya sehingga responden dapat memilih jawaban yang sesuai dengan cara memberikan tanda cek $(\sqrt{ })$ pada kolom jawaban yang telah disediakan. Ilustrasi dilengkapi angka 1-7 sebagai acuan skala untuk menentukan tindakan tidak korupsi (1) dan sangat korupsi (7). Angka 2-6 adalah skala di antara keduanya.

Berdasarkan Tabel 1 daftar ilustrasi pertanyaan dalam kuisioner penelitian adalah sebagai berikut. Pertanyaan 1:A ingin mengikuti penerimaan CPNS. A ingin sekali diterima menjadi CPNS, kemudian secara kebetulan ketua panita penerimaan CPNS tersebut berteman baik dengan ayah A. Ayah A meminta ketua panitia tersebut untuk meloloskan anaknya (A). Ketua panitia CPNS menyetujui keinginan ayah $\mathrm{A}$, tetapi Ayah $\mathrm{A}$ harus memberikan imbalan dengan nominal yang disepakati.

Pertanyaan 2: A adalah salah satu peserta CPNS yang telah dijanjikan oleh B sebagai ketua panitia penerimaan CPNS untuk diloloskan dalam proses seleksi dengan memberikan imbalan tertentu sesuai dengan kesepakatan. Akan tetapi, dalam perjalanan serah terima uang, A terkena OTT oleh
KPK sebelum statusnya sah menjadi CPNS.

Pertanyaan 3: X, direktur BUMN menyuruh stafnya untuk membeli tanah di wilayah Y untuk pembangunan tol dengan tidak sesuai prosedur agar dapat segera membangun tol. Ternyata, Pak Z sebagai lurah di wilayahY memberikan imbalan pada $\mathrm{X}$ karena telah membeli tanah dengan harga lebih tinggi dari pasaran.

Pertanyaan 4: D adalah sekretaris pribadi direktur suatu BUMN. Suatu hari, setelah seorang kolega datang ke ruang direktur, D mendapat uang tips dari direktur tersebut. Meski D tahu bahwa pemberian tips itu berhubungan dengan tindakan korupsi yang dilakukan direktur bersama kolega kemarin, D tetap menerimanya.

Pertanyaan 5: $Z$ adalah siswa SMK yang sedang magang di instansi pemerintahan. $Z$ diminta untuk membuat laporan keuangan kegiatan. Oleh kepala bagian, $\mathrm{Z}$ diminta untuk menyeimbangkan laporan keuangan kegiatan. Dampaknya, laporan keuangan tersebut berbeda dengan anggaran keuangan yang sebenarnya. Sebagai imbalan dari pekerjaan ini, $\mathrm{Z}$ diberi insentif oleh kepala bagian.

Pertanyaan 6: C adalah pegawai di salah satu kantor pemerintahan. Suatu hari, oleh bendahara kantornya, C diberi uang sebesar Rp500.000. Meski tidak tahu untuk apa, R tetap menerima uang.

Pertanyaan 7: A adalah pegawai pajak yang telah mengupayakan nilai pajak $\mathrm{B}$, pengusaha, agar lebih rendah dari kewajiban yang seharusnya dbayarkan. Atas upayanya ini, A akan diberi imbalan berupa uangtunai 500 juta. Ketika dalam perjalanan serah terima uang, A terkena OTT oleh KPK.

Tabel 1. Variabel Kata Korupsi

\begin{tabular}{|c|c|c|c|c|}
\hline Pertanyaan & Variabel 1 & Variabel 2 & Variabel 3 & Variabel 4 \\
\hline Pertanyaan 1 & + & + & + & + \\
\hline Pertanyaan 2 & - & + & + & + \\
\hline Pertanyaan 3 & + & + & + & - \\
\hline Pertanyaan 4 & - & + & + & - \\
\hline Pertanyaan 5 & + & + & - & - \\
\hline Pertanyaan 6 & - & + & - & - \\
\hline Pertanyaan 7 & + & - & + & - \\
\hline Pertanyaan 8 & - & - & - & - \\
\hline Pertanyaan 9 & + & - & + & - \\
\hline Pertanyaan 10 & - & - & + & - \\
\hline Pertanyaan 11 & + & - & - & - \\
\hline Pertanyaan 12 & - & - & - & - \\
\hline
\end{tabular}


Pertanyaan 8: $\mathrm{X}$ berkeinginan untuk menjadi PNS di lingkungan Pemkot Z. Dia mendatangi Y, panitera penerimaan PNS. Saat $X$ mengutarakan keinginan untuk menjadi PNS, Y langsung menghentikan pembicaraan dan menegaskan tidak ada kuota untuk penerimaan melalui jalur tidak sah.

Pertanyaan 9: $\mathrm{X}$, direktur BUMN menyuruh stafnya untuk membeli tanah di wilayah $\mathrm{Y}$ untuk pembangunan tol dengan tidak sesuai prosedur agar dapat segera membangun tol.

Pertanyaan 10: X, PNS di Kementerian Keuangan didatangi $\mathrm{Y}$ yang menjanjikan imbalan berupa uanga tunai 100 juta rupiah jika $X$ bersedia mengurangi jumlah wajib pajak yang harus disetor Y. Akan tetapi, X menolak tawaran dari Y.

Pertanyaan 11: $\mathrm{Z}$ adalah siswa SMK yang sedang magang di instansi pemerintahan. $Z$ diminta untuk membuat laporan keuangan kegiatan. Oleh kepala bagian, $\mathrm{Z}$ diminta untuk menyeimbangkan laporan keuangan kegiatan. Dampaknya, laporan keuangan tersebut berbeda dengan anggaran keuangan yang sebenarnya. Tanpa berpikir apa-apa, Z melakukan permintaan tersebut.

Pertanyaan 12: R, siswa SMK yang sedang magang di instansi pemerintah. Suatu hari, ia diminta seorang pegawai untuk menandatangani sebuah kertas kosong yang ia tidak tahu untuk apa. Karena merasa curiga, $\mathrm{R}$ memutuskan untuk tidak melakukannya.

Setelah pengisian kuisioner, selanjutnya peneliti melakukan uji validitas data. Validitas data dilihat melalui jawaban pada pertanyaan kontrol, yaitu pertanyaan 1 dan 12 . Artinya, hanya responden yang merepon dengan tepat pada pertanyaan 1 dan 12 yang akan dianalisis lebih lanjut. Pertanyaan 1 memuat nilai positif pada ketiga variabel dan pertanyaan12 memiliki nilai negatif pada ketiga variable. Jika terdapat responden yang merespon pertanyaan 12 dengan nilai tinggi atau lebih tinggi dari pertanyaan 1 , maka kuisioner responden tersebut dianggap tidak valid. Hal tersebut disebabkan ketidakseriusan responden dalam mengisi kuesioner.

Data yang dianggap valid direkapitulasi dan dianalisis. Analisis yang digunakan adalah analisis deskriptif kuantitatif-kualitatif. Disebut kualitatif karena menggunakan angka sebagai data dan kualitatif karena angka tersebut kemudian ditafsirkan oleh peneliti. Analisis data dilakukan dalam dua tahap. Tahap pertama bertujuan untuk mengetahui derajat korupsi pada masing-masing variabel. Tahap kedua bertujuan untuk memolakan latar belakang responden dan penilaian pada masing-masing pertanyaan.

Tahap pertama dilakukan dengan menghitung nilai pada masing-masing peryataan. Selanjutnya, nilai tersebut ditafsirkan: (1) nilai paling tinggi menunjukkan tindakan paling korupsi dan (2) nilai paling rendah menujukkan derajat korupsi yang rendah. Setelah itu, nilai korupsi pada setiap variabel dianalisis. Misalnya, pertanyaan 2 memiliki nilai korupsi lebih tinggi dibanding pertanyaan 3 . Hal ini berindikasi nilai korupsi variabel 1 lebih rendah daripada variabel 3 .

Selain melihat derajat korupsi dari masingmasing variabel, analisis data juga dilakukan pada latar belakang responden. Oleh karena itu, dalam angket penelitian disertakan pula data informan, meliputi jenis kelamin, strata pendidikan, jabatan, dan usia. Data ini digunakan untuk melacak faktor yang melatarbelakangi seseorang memberikan nilai pada masing-masing pertanyaan.

Tahap kedua dilakukan dengan mengklasifikasikan data berdasarkan latar belakang informan, seperti jenis kelamin, strata pendidikan, pengetahuan awal berkaitan dengan korupsi, dan usia. Selanjutnya, dilihat pola tertentu pada klasifikasi masing-masing. Sebagai contoh, apakah strata pendidikan mempengaruhi pilihan responden dalam melihat salah satu variabel korupsi?

\section{HASIL}

Paparan hasil penelitian disajikan berdasarkan variabel penyalahgunaan kewenangan, terdapat imbalan yang tidak sah, tahu kalau itu korupsi, dan ada niat untuk korupsi. Hasil angket secara umum menunjukkan bahwa pertanyaan nomor 7 memeroleh skor tertinggi, sedangkan pertanyaan nomor 12 memeroleh skor terendah (selengkapnya lihat Tabel 1). Hipotesis yang menyatakan bahwa poin tertinggi diperoleh dari pertanyaan yang keempat variabelnya positif tidak terbukti. Namun demikian, hipotesis yang menyatakan bahwa poin terendah diperoleh dari pertanyaan yang keempat variabelnya negatif terbukti. Penyajian hasil penelitian ini ditunjukkan pada Tabel 1 . 
Tabel 2. Hasil Pe nelitian Prototipe Semantik Korupsi

\begin{tabular}{ccccc}
\hline Peringkat & Deskripsi & Variabel & Total Akhir & Rata-rata \\
\hline 1 & 7 & +-++ & 192 & 6,33 \\
\hline 2 & 1 & ++++ & 182 & 6,06 \\
\hline 3 & 5 & ++-- & 170 & 5,66 \\
\hline 4 & 2 & -+++ & 166 & 5,53 \\
\hline 5 & 4 & -++- & 160 & 5,33 \\
\hline 6 & 3 & +++- & 158 & 5,26 \\
\hline 7 & 11 & +--- & 147 & 4,9 \\
\hline 8 & 9 & +-+- & 138 & 4,6 \\
\hline 9 & 6 & -+-- & 114 & 3,8 \\
\hline 10 & 10 & --+- & 59 & 1,96 \\
\hline 11 & 8 & --++ & 42 & 1,4 \\
\hline 12 & 12 & ---- & 36 & 1,2 \\
\hline
\end{tabular}

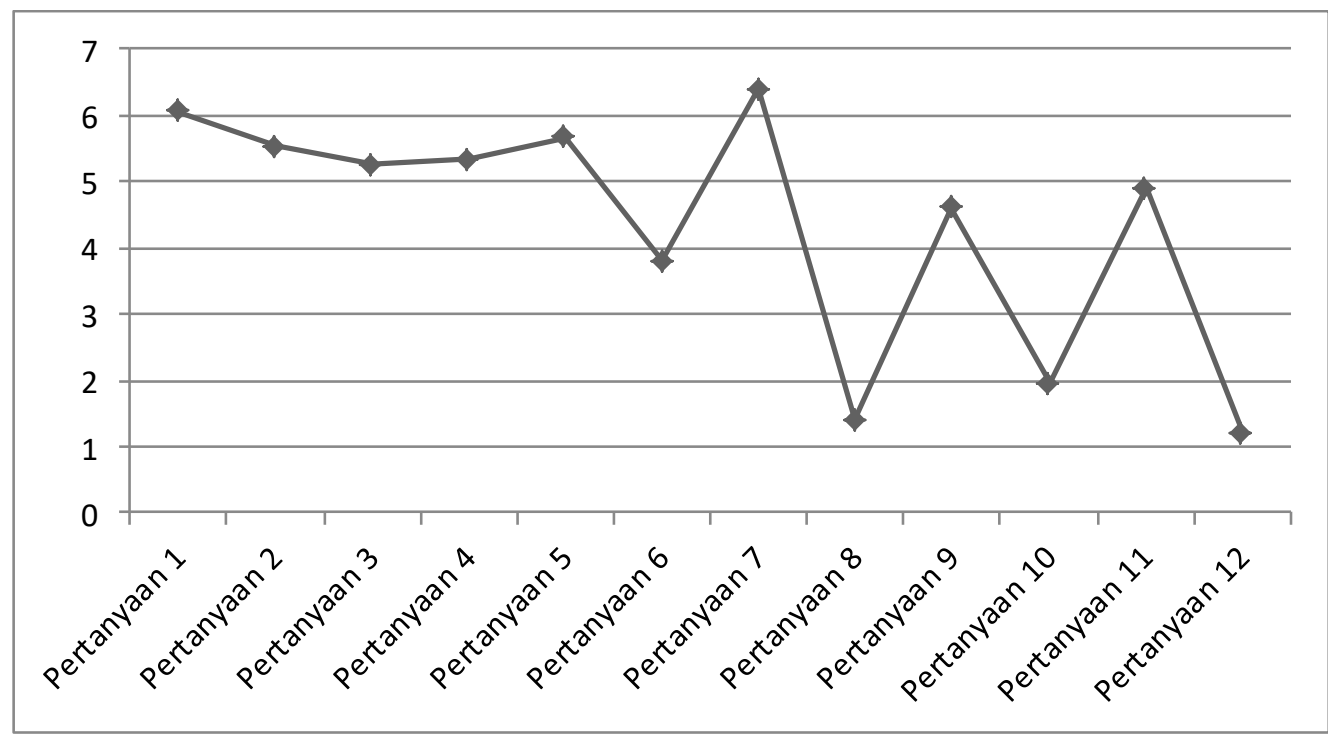

Diagram 1. Rata-Rata Prototipe Semantik Korupsi

Tabel 3. Variabel yang Paling Berpengaruh

\begin{tabular}{ccccc}
\hline Peringkat & Deskripsi & Variabel & Total Akhir & Rata-rata \\
\hline 1. & 7 & +-++ & 192 & 6,33 \\
\hline 2. & 1 & ++++ & 182 & 6,06 \\
\hline 3. & 5 & ++-- & 170 & 5,66 \\
\hline 4. & 2 & -+++ & 166 & 5,53 \\
\hline 5. & 4 & -++- & 160 & 5,33 \\
\hline 6. & 3 & +++- & 158 & 5,26 \\
\hline
\end{tabular}

Berdasarkan hasil penelitian, ditemukan bahwa pertanyaan yang mendapatkan poin tertinggi (paling korupsi) adalah pertanyaan $7(+-++)$. Pada pertanyaan ini, tertulis bahwa besar nilai korupsi adalah Rp 500 juta, berbeda dengan pertanyaan lain yan memiliki nominal korupsi lebih rendah atau bahkan tidak disebutkan nominalnya. Hal ini menunjukkan bahwa semakin tinggi nominal keru- 
gian negara dianggap semakin korupsi. Selanjutnya, hipotesis "pertanyaan dengan variabel positif lebih banyak akan memperoleh nilai lebih tinggi daripada pertanyaan dengan variabel positif lebih sedikit" juga tidak terbukti. Hal itu terlihat pada pertanyaan $5(++--)$ yang mendapatkan poin lebih tinggi daripada pertanyaan $2(-+++)$.

Tabel 3 membuktikan bahwa pada peringkat 1 (pertanyaan 7), sebagaimana disampaikan sebelumnya mengandung kerugian negara tertinggi sebesar RP 500 juta. Selanjutnya, pada peringkat 2 (pertanyaan 1), peringkat 3 (pertanyaan 5), peringkat 4 (pertanyaan 2), peringkat 5 (pertanyaan 4), dan peringkat 6 (pertanyaan 3) variabel 'terdapat imbalan yang tidak sah' selalu dalam bentuk positif. Hal ini menunjukkan bahwa variabel 'terdapat imbalan yang tidak sah' adalah variabel paling berpengaruh dalam menentukan derajat korupsi.

Variabel yang kedua yang berpengaruh dalam tingkat korupsi adalah variabel 'adanya penyalahgunaan kewenangan'. Pertanyaan yang memuat variabel ini berada pada peringkat 6,7 , dan 8 . Paparan lebih rinci dapat dilihat Tabel 4.

Dua variabel terakhir, yaitu tahu bahwa itu korupsi dan berniat korupsi merupakan variabel yang paling rendah dalam mempengaruhi tingkat korupsi. Kedua variabel ini saling berhubungan, sehingga keduanya tidak dapat dirinci dalam pemeringkatan variabel.

Selain dipengaruhi oleh empat variabel, dalam pemeringkatan korupsi juga dipengaruhi oleh latar belakang responden. Responden dari bidang hukum (dosen dan mahasiswa Fakultas Hukum) memberi skor tinggi pada pertanyaan yang memuat variabel 1 (terdapat penyalahgunaan kewenangan) dan 2 (terdapat imbalan yang tidak sah). Sementara itu, variabel 3 (tahu bahwa itu korupsi) dan variabel 4 (berniat untuk korupsi) tidak memiliki pengaruh yang besar dalam penilaian mereka.

Berdasarkan latar belakang pendidikan responden, tidak ada perbedaan pemeringkatan korupsi dengan pemeringkatan derajat korupsi secara umum, yaitu (1) terdapat imbalan yang tidak sah, (2) terdapat penyalahgunaan kewenangan' (3) 'tahu bahwa itu korupsi' dan 'berniat korupsi'. Akan tetapi, terdapat perbedaan di antara responden dari bidang hokum dan non-hukum. Responden dari bidang non-hukum menilai bahwa pertayaan no-

Tabel 4. Variabel Penyalagunaan Kewenangan

\begin{tabular}{ccccc}
\hline Peringkat & Deskripsi & Variabel & Total Akhir & Rata-rata \\
\hline 6. & 3 & +++- & 158 & 5.26 \\
\hline 7. & 11 & +--- & 147 & 4.9 \\
\hline 8. & 9 & +-+- & 138 & 4.6 \\
\hline
\end{tabular}

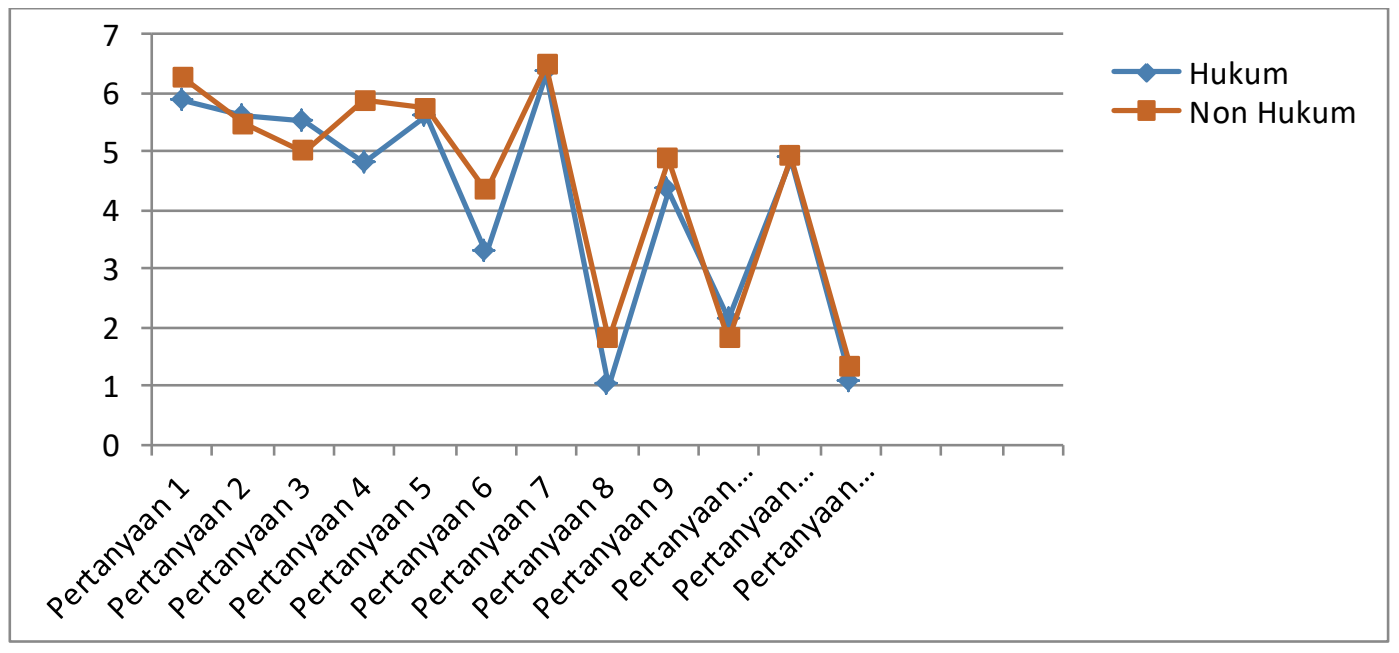

Diagram 2. Rata-rata Prototipe Korupsi Berdasarkan Bidang Pendidikan Responden 


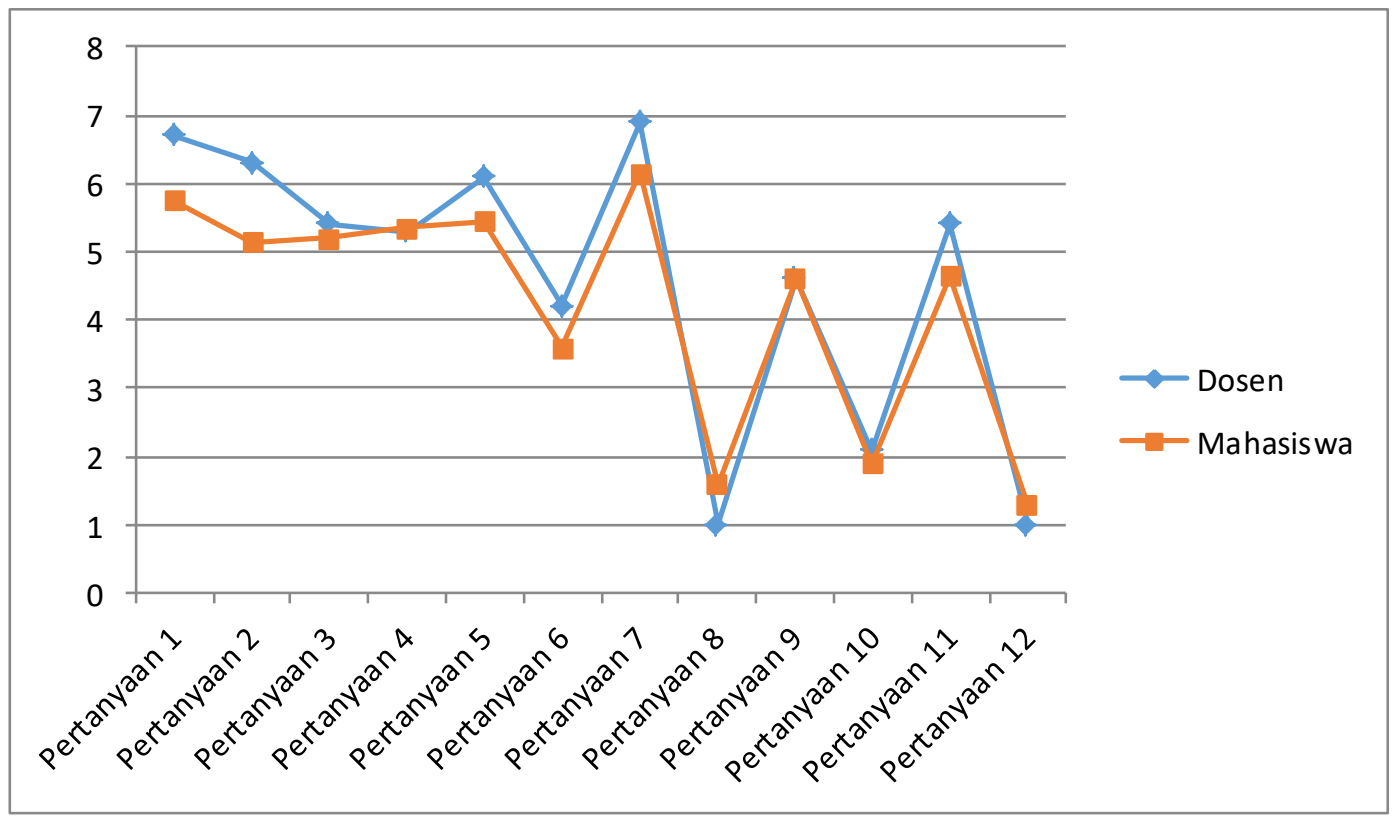

Diagram 3. Rata-Rata Prototipe Korupsi Berdasarkan Pekerjaan Responden

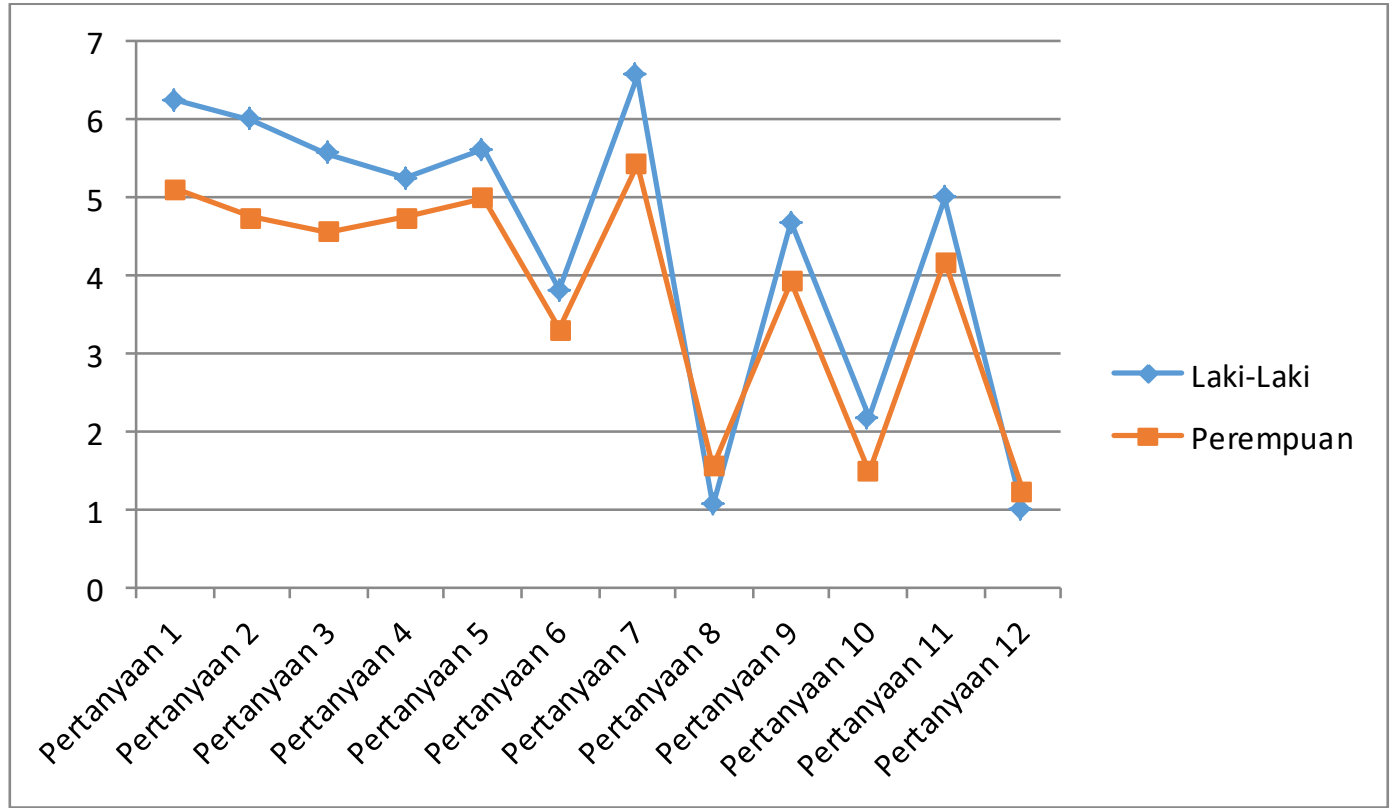

Diagram 4 Rata-Rata Prototipe Korupsi Berdasarkan Jenis Kelamin Responden

mor 4 (-++-) lebih korupsi daripada pertanyaan nomor $5(++-)$.

Berbeda dengan responden dari hukum yang menilai pertanyaan nomor 5 (++--) lebih korupsi daripada pertanyaan nomor 4 , responden dari bidang non-hukum menilai bahwa pertanyaan nomor
6 (-+--) dengan skor lebih tinggi (rata-rata 4,33) dibandingkan responden dari bidang hukum (ratarata 3,26). Responden dari bidang hukum menganggap pertanyaan $8(--++)$ dianggap lebih tidak korupsi dibanding pertanyaan 12 (----). Pada pertanyaan 8 , responden dari bidang non-hukum me- 
nilai lebih korupsi (rata-rata 1,8) dibandingkan responden bidang hukum yang memberi skor rata-rata 1. Hal ini menunjukkan bahwa variabel pertama dan kedua lebih mempengaruhi kadar korupsi dibanding variabel 3 dan 4 bagi responden dari bidang hukum.

Berdasarkan latar pekerjaan responden, tidak ada perbedaan pemeringkatan korupsi dengan pemeringkatan secara umum, yaitu (1) terdapat imbalan yang tidak sah, (2) terdapat penyalahgunaan kewenangan' (3) 'tahu bahwa itu korupsi' dan 'berniat korupsi'. Akan tetapi, terdapat sedikit perbedaan antara responden yang masih mahasiswa dan responden yang bekerja sebagai dosen. Berdasarkan Diagram 3, diperoleh kesimpulan bahwa responden dari dosen cenderung memberi skor lebih tinggi daripada mahasiswa kecuali pada pertanyaan 8 dan pertanyaan 12 . Pertanyaan $8(--++)$ menunjukkan bahwa dosen tidak mempertimbangkan variabel "tahu bahwa itu korupsi" dan "niat untuk korupsi". Dosen lebih mempertimbangkan dua variabel pertama, yaitu "terdapat penyalahgunaan ke-wenangan" dan "terdapat imbalan yang tidak sah". Hal tersebut terbukti pada pertanyaan 1 $(+++)$, pertanyaan $2(-+++)$, pertanyaan $5(++-)$, pertanyaan $6(-+--)$, pertanyaan $7(+-++)$, dan pertanyaan 11 (+---), dosen memberi skor lebih tinggi daripada mahasiswa.

Berdasarkan jenis kelamin juga tidak terdapat perbedaan urutan derajat korupsi, yaitu (1) terdapat imbalan yang tidak sah, (2) terdapat penyalahgunaan kewenangan' (3) 'tahu bahwa itu korupsi' dan 'berniat korupsi'. Berdasarkan diagram 4, dapat disimpulkan bahwa responden laki-laki memberikan skor yang lebih tinggi pada semua pertanyaan, kecuali pada pertanyaan $8(--++)$ dan pertanyaan 12 (----).Hal ini menunjukkan, responden perempuan memberi skor lebih tinggi pada variabel "tahu bahwa itu korupsi" dan "niat korupsi”. Berbeda dengan laki-laki yang lebih abai dengan hal yang bersifat absurd, seperti pengetahuan pelaku korupsi dan niat korupsi.

\section{Pembahas an}

Berdasarkan hasil penelitian ditemukan bahwa tidak ada perbedaan persepsi korupsi berdasarkan latar belakang pendidikan responden. Gradasi perbedaan skor yang mencolok berdasarkan latar belakang pendidikan disebabkan mahasiswa dan dosen dari Fakultas Hukum memahami bahwa dalam koridor hukum, semua orang dianggap tahu hukum. Hal ini dikenal dalam Teori Fiksi Hukum. Teori Fiksi Hukum beranggapan bahwa setelah norma hukum diberlakukan, setiap orang dianggap tahu hukum (Marwan, 2016). Ketidaktahuan seseorang akan hukum tidak dapat membebaskannya dari tuntutan hukum (As Shiddiqie, 2008). Hal ini yang menyebabkan variabel ketiga tidak berpengaruh dalam penentuan korupsi atau tidaknya seseorang. Lebih lanjut, niat korupsi merupakan hal yang bersifat absurd yang tidak dapat dibuktikan dengan pasti di hadapan hukum. Oleh karena itu, dua variabel tersebut dianggap tidak berpengaruh. Selain itu, dalam kacamata hukum, yang dinilai adalah dampak perbuatan, bukan proses perbuatan. Semakin besar kerugian negara, semakin tinggi tingkat korupsinya sehingga pertanyaan $7(+-++)$ yang merugikan negara $\mathrm{Rp} 500$ juta (nilai kerugian tertinggi dalam deskripsi kuisioner pada penelitian ini) mendapat skor tinggi (rata-rata 6,33) dibanding pertanyaan $1(++++)$ dengan rata-rata 5,86 .

Selanjutnya, ditemukan bahwa ada perbedaan persepsi korupsi berdasarkan pekerjaan responden antara seorang dosen dan mahasiswa S1. Seorang Dosen telah menerima ilmu pengetahuan lebih banyak dan terlebih dahulu daripada mahasiswa. Seorang dosen telah menempuh jenjang studi S1 dan paling minimal S2 jika ingin menjadi dosen, hal tersebut menjadi indikasi bahwa capaian ilmu yang di dapat antara dosen dan mahasiswa S1 juga sudah berbeda. Dilihat dari segi tuntutan pekerjaan juga sedikit banyak memengaruhi. Dosen dituntut lebih untuk melakukan penelitian dan pengembangan pemikiran sehingga mereka harus memperluas ilmu pengetahuannya, sedangkan mahasiswa terkadang hanya menerima ilmu yang diperoleh dari Dosen. Adanya streotip yang menganggap dosen harus lebih pintar dari mahasiswa juga menjadi pemacu dosen untuk lebih berpikir kritis dan menerapkan ilmu yang didapat dalam memberikan sumbangsih ilmu pengetahuannya. Menurut Syam (dalam Ridhwan, 2017) pngembangan profesi dosen, meliputi empat kompetensi, yaitu kompetensi pedagogis, kepribadian, profesional, dan sosial sehingga dari tuntutan penguasaan kompetensi tersebut terlihat adanya perbedaan pemikiran antara dosen dan mahasiswa.

Berdasarkan hasil penelitian terungkap ada- 
nya perbedaan persepsi definis korupsi antara perempuan dan laki-laki. Perbedaan persepsi berdasarkan jenis kelamin dapat dipahami berdasarkan streotipe yang berkembang dalam masyarakat. Selama ini laki-laki biasanya diangap lebih rasional dan logis dan perempuan lebih emosional dan penuh perasaan (Shield dalam Khairani, 2009 dan Kahn dalam Khairani, 2009). Perbedaan itu juga dapat disebabkan oleh perbedaan hormonal dan kondisi psikologis antara pria dan wanita (Young dalam Khairani, 2009). Hal ini dapat memengaruhi persepsi mereka dalam melihat prototipe korupsi. Oleh karena itu, wajar jika responden perempuan memberi skor lebih tinggi pada variabel "tahu bahwa itu korupsi" dan "niat korupsi". Berbeda dengan laki-laki yang lebih abai dengan hal yang bersifat absurd, seperti pengetahuan pelaku korupsi dan niat korupsi. Hal ini dapat disebabkan oleh sikap lelaki yang lebih rasional dan logis dalam menilai tindakan korupsi.

Penelitian tentang prototipe korupsi ini menunjukkan bahwa variabel (3) tahu bahwa itu korupsi dan (4) niat korupsi merupakan variabel yang paling tidak prototipikal korupsi. Terdapat dua alasan mendasar yang menyebabkan hal tersebut. Pertama, bagi orang yang paham hukum, baik pelaku mengetahui dan berniat korupsi atau tidak, jika ia mendapatkan imbalan yang tidak sah dan merugikan negara, ia tetap dianggap koruptor, sesuai dengan Teori Fiksi Hukum. Kedua, bagi orang yang tidak paham hukum dan tidak tahu ada Teori Fiksi Hukum, variabel tahu dan niat adalah variabel yang absurd dan tidak dapat diukur dengan mudah, berbeda dengan penyalahgunaan kewenangan dan adanya imbalan yang tidak sah.

Hal ini sekaligus menunjukkan bahwa terdapat gradasi derajat korupsi dalam variabel korupsi masing-masing. Ada variabel yang sangat korupsi, yaitu adanya imbalan yang tidak sah dan penyalahgunaan kewenangan dan ada variabel yang tidak prototipikal korupsi, yaitu tahu bahwa itu korupsi dan niat korupsi. Hal ini juga mengindikasikan bahwa ketidakpuasan terhadap semantik struktural yang melihat semua anggota yang membentuk suatu kategori memiliki nilai yang sama. Semisal, dalam kasus pendefinisian korupsi, bahwa imbalan yang tidak sah dan tahu bahwa itu korupsi memiliki derajat yang sama. Melalui teori prototipe, terbukti bahwa keanggotaan suatu kategori bersifat gradasi.
Artinya, ada anggota yang prototipikal kategori tersebut, ada yang kurang prototipikal.

Penelitian ini juga membuktikan bahwa nominal kerugian negara yang besar dapat mempengaruhi derajat prototipe korupsi. Artinya, ada indikasi bahwa semakin besar kerugian negara, semakin tipikal korupsi. Akan tetapi, kajian entang besarnya nominal korupsi, tidak diukur dalam penelitian. Oleh karena itu, penelitian ini membutuhkan penelitian lanjutan mengenai hubungan nominal kerugian negara dengan derajat korupsi.

Dibandingkan dengan penelitian sejenis sebelumnya, hasil penelitian ini menyatakan bahwa semakin tinggi nominal kerugian negara dianggap semakin korupsi. Rata-rata prototipe korupsi berdasarkan asal responden, responden berlatar belakang dosen yang berkecimpung dalam keilmuan bidang hukum dan nonhukum. Responden juga berasal dari mahasiswa dari bidang hukum dan non hukum. Selain itu peneliti yang mengelompokkan dari jenis kelamin, responden laki-laki dan responden perempuan. Pengategorian responden tersebut dimasudkan agar data yang diperoleh bervariasi dan dapat mengerucut pada satu kesimpulan dari prototipe korupsi.

Temuan ini sekaligus menegaskan bahwa dalam kajian terkait prototipe, terdapat dua aspek yang memengaruhi derajat prototipe suatu kategori, yaitu variabel anggota kategori dan latar belakang responden. Temuan ini juga menguatkan posisi semantik kognitif yang melihat adanya gradasi makna suatu leksem yang tidak bersifat biner semata. Hal ini selanjutnya dapat digunakan sebagai acuan penyusunan makna dalam kamus generasi baru. Terakhir, gradasi makna dari variabel korupsi dapat menjadi patokan dalam menyusun kurikulum pendidikan antikorupsi sekaligus dasar pengambilan sanksi bagi tindak pidana korupsi. Selain itu gradasi makna dari variabel korupsi dapat menjadi pertimbangan mengenai tingkat pemaknaan derajat korupsi.

\section{SIMPULAN}

Berdasarkan hasil dan pembahasan dapat disimpulkan bahwa variabel korupsi yang paling memengaruhi derajat korupsi adalah (1) 'terdapat imbalan yang tidak sah' dan (2) 'terdapat penyalah- 
gunaan kewenangan'. Sementara itu, dua variabel lain, yaitu 'tahu bahwa itu korupsi' dan 'berniat korupsi' cenderung tidak memengaruhi pemeringkatan derajat korupsi. Berdasarkan latar belakang responden, tidak ada perbedaan urutan derajat korupsi, yaitu (1) terdapat imbalan yang tidak sah, (2) terdapat penyalahgunaan kewenangan' (3) 'tahu bahwa itu korupsi' dan 'berniat korupsi'.

Berdasarkan latar belakang pendidikan responden, responden dari bidang hukum menilai bahwa 'penyalahgunaan kewenangan' dan 'terdapat imbalan yang tidak sah'memengaruhi derajat korupsi. Sementara variabel 'tahu bahwa itu korupsi' dan 'berniat korupsi' dianggap tidak berpengaruh sama sekali. Hal ini berbeda dengan responden dari selain bidang hukum yang masih menilai variabel 'tahu bahwa itu korupsi' dan 'berniat korupsi' yag menganggap kedua hal ini penting bagi penilaian tindakan ersebut korupsi atau tidak.

Berdasarkan latar belakang pekerjaan res-

\section{DAFTAR RUJUKAN}

Ayatullah, A. L. 2014. Korupsi dalam Wacana Pers Lokal: Analisis Wacana Kritis Norman Fairclough terhadap Teks Berita Kasus Hambalang Tahun 2013 ada Surat Kabar Malang Post. Jurnal Mahasiswa Sosiologi,3(1):1-16.

Azra, A. 2002. Korupsi dalam Perspektif Good Governance. Jurnal Kriminologi Indonesia, 2(1): 3136.

Coleman, L. and P. Kay. 1981. Prototype Semantics: The English Word Lie. Language, 57(1): 26-44

Creswell, J., W. 2012. Research Design Pendekatan Kualitatif, Kuantitatif, dan Mixed. Yogyakarta: Pustaka Pelajar

Croft, W. and D. A. Cruse. 2004. Cognitive Li-nguistics. London: Cambridge University Press.

Geeraterts, D. 2006. Prospects and Problems of Prototype Theory. Dalam Dirk Geeraterts, dkk. (Ed). Cognitive Linguistics Basic Readings(page 141-166). Berlin dan New York: Mouton de Gruyter,

Geeraterts, D. 2016. Prospect and Problems of Prototype Theory. Diacronia, 3(1): 1-16.

Indonesia Corruption Wacth (ICW). 2017. Trend Penindasan Kasus Korupsi Tahun 2017. Bahan Presentasi. (online). https://antikorupsi.org/sites/ default/files/tren_korupsi_2017.pdf

Kamus Besar Bahasa Indonesia. 2008. Jakarta: Pusat Bahasa ponden, dosen cenderung memberi nilai tinggi pada variabel "terdapat penyalahgunaan kewenangan" dan "terdapat imbalan yang tidak sah" dibanding mahasiswa. Sementara itu, berdasarkan jenis kelamin, responden perempuan memberi skor lebih tinggi pada variabel "tahu bahwa itu korupsi" dan "niat korupsi" dibanding responden pria. Temuan penelitian mengonfirmasi bahwa dalam kajian prototipe terdapat dua aspek yang memengaruhi derajat prototipe suatu kategori, yaitu variabel anggota kategori dan latar belakang responden.

\section{UCAPAN TERIMA KASIH}

Ucapan terima kasih diberikan kepada seluruh responden yang bersedia mengisi angket penelitian selama pengumpulan data penelitian. Selanjutnya, ucapan terima kasih diberikan pula kepada mitra bestari (reviewers)yang telah memberikan saran, kritik, dan rekomendasi perbaikan artikel ini.

Khairani, R. dan Putri D. E. 2009. Perbedaan Kematangan Emosi pada Pria dan Wanita yag Menikah Muda. Makalah Disajikan Dalam Proceeding PESAT (Psikologi, Ekonomi, Sastra, Arsitektur, \& Sipil) Universitas Gunadarma, 20-21 Oktober 2009.

Kushartanti, U. Y. dan M. Lauder. 2010. Pesona Bahasa. Jakarta: Gramedia.

Lipka, L. 1986. Linguistics across Historical and Geographical Boundaries. Berlin: Walter

Marwan, A. 2016. Mengkritisi Pemberlakuan Teori Fiksi Hukum. Jurnal Penelitian Hukum De Jure, 16(3): 251-264.

Nurjannah. 2013. Semantik Prototipe pada Leksem Bule melalui Kognisi Orang Indonesia. Prosiding Seminar Internasional Studi Bahasa dari Berbagai Perspektif dalam Rangka Ulang Tahun ke-80 Prof. Dr. Soepomo Poedjosoedarmo. hlm. 755765. Yogyakarta: Universitas Gadjah Mada.

Pasaribu, T. A.. 2013. Analisis Linguistik Kognitif pada Polisemi Leksem CUT. Tesis. Yogyakarta: FIB Universitas Gadjah Mada.

Prayudha. 2013. Analisis Prototipe Semantik Korupsi 'Penyuapan' sebagai Perspektif Alternatif Pemberantasan Korupsi: Studi Linguistik Antropologis. (Online). http://www.academia.edu/ 8148397/ANALISIS SEMANTIK PROTOTIPE KO RUPSI_SEBUAH_KAJIAN_LINGUISTIK_KO 
GNITIF). Diakses tanggal 13 Maret 2018

Ridhwan. 2017. Strategi Belajar dan Mengajar di Perguruan Tinggi. (Online). http://stitahs.com/ artikel-dosen/23-artikel-dosen-stit/27-strategimengajar-dan-belajar-di-perguruan-tinggi. Diakses 31 Agustus 2018
Sina, L. 2008. Dampak dan Upaya Pemberantasan serta Pengawasan Korupsi di Indonesia. Jurnal Hukum Pro Justisia, 26(1): 39-45.

Tanzi, V. 1998. Corruption Around the World: Causes, Consequences, Scopes, and Cures. IMF Working Paper. IMF Fiscal Affairs Department. 